\title{
sien \\ First isolation of the Mycosphaerella graminicola teleomorph stage causing Septoria leaf blotch on wheat in Tunisia
}

\author{
A. Ben hassine ${ }^{1 *}$ and W. Hamada ${ }^{1,2}$ \\ ${ }^{1}$ Laboratory of Genetics and Plant Breeding, Institut National Agronomique de Tunisie 43, Avenue Charles Nicolle \\ 1082-Tunis-Mahrajène Tunisia; ${ }^{2}$ Higher School of Agriculture of Kef (ESAK) boulifa 7119-kef, Tunisia
}

*E-mail: abir.benhassine@hotmail.fr

Received: 13 Nov 2013. Published: 05 May 2014. Keywords: ascospores, Burkard spore trap, cytochrome b, mating types, PCR

Durum wheat is the most important cereal crop in Tunisia covering more than 800,000 ha, of which 150,000 ha are chemically treated each year. The average productivity is below its potential yield due to pathogen stress during critical growth stages. Leaf blotch, caused by Zymoseptoria tritici (teleomorph: Mycosphaerella graminicola), is the major leaf disease in Tunisia affecting over $40 \%$ of the total durum wheat acreage during favourable seasons. Up to now, only the anamorph stage has been collected from wheat fields in Tunisia. However, the presence of the teleomorph stage would contribute significantly to the emergence of new strains, due to genetic recombination resulting from sexual reproduction, which could be spread over long distances.

In 2013, three ascospores, labelled A1, A2 and A3, were isolated from a durum wheat field in Mateur (North of Tunisia) using a Burkard spore trap and transferred on to potato dextrose agar (Fig. 1) for further studies. The ascospores were identified initially as $M$. graminicola based on microscopic observation of their size $(11 \mu \mathrm{m} \times 2.5 \mu \mathrm{m})$ and the shape of their germ tubes after incubation in comparison with a previous report (Sanderson \& Hampton, 1978). PCR was performed on the DNA extracted from mycelium of these isolates grown in yeast extract glucose medium using a STC-F/STC-R Cytochrome b specific primer pair to confirm their identity (Fraaije et al., 2005). All three isolates gave PCR products of expected sizes for M. graminicola (248 bp) (Fig. 2). The mating type of each isolate was studied using Mat1-1F/R and Mat1-2F/R on multiplex PCR (Waalwijket al., 2002). Based upon the identifying band, isolate A1 was identified as Mat1-2 (660 bp), while isolates A2 and A3 were identified as Mat1-1 (340 bp) (Fig. 3). Distribution of both mating types within a population of M. graminicola in a plot with an area of $36 \mathrm{~m}^{2}$ was studied using multiplex PCR. Both mating types were found among fungal strains sampled from different lesions of the same leaf as well as in equal proportions from different pycnidia in the same lesion. This coexistence of both mating types decreases over time in parallel with the reduction of ascospore discharge captured by the spore trap. These results support the contribution of the sexual cycle of M. graminicola in primary infections of the wheat crop and its subsequent dissemination in Tunisia.

Daily discharge of ascospores was assessed in the field through a Burkard spore trap placed in a durum wheat field in Mateur from 16 February to 22 March, 2013. Results revealed ascospore release from 16 February to 6 March, with a maximum number of 25 ascospores $/ \mathrm{m}^{3}$ trapped (Fig. 4). In addition, discharge is closely related to rainfall events with maximum discharge of ascospores when the cumulative rainfall is between 15 and 30 $\mathrm{mm}$ during the three to five days before the day of discharge. This correlation between rainfall and ascospore discharge was also observed by Magboul et al. (1992).

This is the first report of $M$. graminicola ascospores collected from environmental samples in Tunisia. An earlier study (Boukef et al., 2012) confirmed the presence of both mating types, but only by collecting and analysing spores of the anamorph. Cropping practices that limit the spread of this pathogen, such as the control of imported plant material and removing crop debris from harvested fields, should be considered. This would contribute to the reduction of the main source of primary inoculum, thereby decreasing genetic recombination causing the emergence of new resistant strains.

\section{References}

Boukef S, Bruce AMcD, Yahyaoui A, Rezgui S, Brunner P, 2012.

Frequency of mutations associated with fungicide resistance and population structure of Mycosphaerella graminicola in Tunisia. European Journal of Plant Pathology 132, 111-122. http://dx.doi.org/10.1007/s10658-011-9853-8

Fraaije BA, Cools HJ, Fountaine J, Lovell DJ, Motteram J, West JS, Lucas JA, 2005. Role of ascospores in further spread of QoI-resistant cytochrome $\mathrm{b}$ alleles (G143A) in field populations of Mycosphaerella graminicola. Phytopathology 95, 933-941. http://dx.doi.org/10.1094/PHYTO-95-0933

Magboul AM, Geng S, Gilchrist DG, Jackson LF, 1992. Environmental influence of the infection of wheat by Mycosphaerella graminicola. Phytopathology 82, 1407-1413. http://dx.doi.org/10.1094/Phyto-82-1407

Sanderson FR, Hampton JG, 1978. Role of the perfect states in the epidemiology of the common Septoria diseases of wheat. New Zealand Journal of Agricultural Research 21, 277-281. http://dx.doi.org/10.1080/00288233.1978.10427411

Waalwijk C, Mendes O, Verstappen ECP, de Waard MA, Kema GH J, 2002. Isolation and characterization of the mating-type idiomorphs from the wheat Septoria leaf blotch fungus Mycosphaerella graminicola. Fungal Genetics and Biology 35, 277-286.

http://dx.doi.org/10.1006/fgbi.2001.1322

Zhan J, Kema GHJ, Waalwijk C, McDonald BA, 2002. Distribution of mating type alleles in the wheat pathogen Mycosphaerella graminicola over spatial scales from lesions to continents. Fungal Genetics and Biology 36, 128-136. http://dx.doi.org/10.1016/S1087-1845(02)00013-0

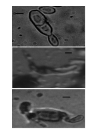

Figure 1

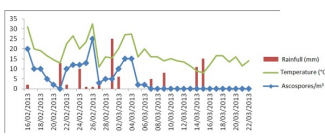

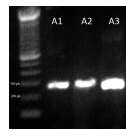

Figure 2

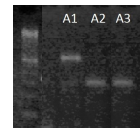

Figure 3

Figure 4

To cite this report: Ben hassine A, Hamada W, 2014. First isolation of the Mycosphaerella graminicola teleomorph stage causing Septoria leaf blotch on wheat in Tunisia. New Disease Reports 29, 18. http://dx.doi.org/10.5197/j.2044-0588.2014.029.018

(c) 2014 The Authors

This report was published on-line at www.ndrs.org.uk where high quality versions of the figures can be found. 